\title{
Prehod »potencialno« nadarjenega otroka iz vrtca v šolo
}

\author{
Aleksandra Kambič \\ Osnovna šola Vič \\ aleksandra.kambic@gmail.com \\ Mojca Kukanja Gabrijelčič \\ Univerza na Primorskem \\ mojca.k.gabrijelcic@pef.upr.si
}

Prehod otrok iz vrtca v osnovno šolo je slabo raziskan, še posebej pa to velja za nadarjene otroke. Prehod mora temeljiti na vertikalni povezavi, ustrezni pedagoški in strokovni kontinuiteti dela z otrokom ter na razumevanju otrokovih značilnosti, ki bodo ustrezno in optimalno upoštevane v nadaljnjem vzgojnoizobraževalnem procesu. V študiji primera kritično analiziramo področje dela s potencialno nadarjenim ( $v$ nadaljevanju nadarjenim) otrokom v vrtcu in šoli ter razkrivamo anomalije $v$ procesu prehoda nadarjenega otroka. Opozorimo na vrsto vrzeli, ki se dotikajo predvsem pedagoške, strokovne in razvojne kontinuitete, razkoraka med kurikuli/učnimi načrti in programskimi smernicami za delo z nadarjenimi, pedagoških pristopov in pomanjkanja sodelovanja med deležniki v procesu prenosa temeljnih informacij o nadarjenemu otroku. Apeliramo na upoštevanje temeljnih pravic nadarjenih otrok v procesu vzgoje in izobraževanja, vrednot, ciljev, konceptov, razumevanja in praks pri delu z nadarjenimi v predšolskem in osnovnošolskem obdobju.

Ključne besede: nadarjenost, prehod, vrtec, osnovna šola, starši

\section{Uvod}

V sodobnem času se veliko sistematičneje in odgovorneje posvečamo nadarjenim posameznikom, saj lahko bistveno prispevajo k napredku razvoja družbe. Razvoja nadarjenega posameznika namreč ne gre prepustiti naključju, posameznika je potrebno odkriti, usmerjati in negovati, da bo razvil svoje potenciale v skladu s svojimi biološkimi danostmi (Juriševič 2011). Najoptimalnejše obdobje za identifikacijo nadarjenosti je predšolska stopnja, saj sta tvorjenje povezav in število ustvarjenih povezav med nevroni do sedmega leta starosti otroka največja (Rajović 2010; 2013). Pomen zgodnjega odkrivanja potencialno nadarjenih ${ }^{1}$ otrok ( $v$ nadaljevanju nadarjenih) poudar-

\footnotetext{
${ }^{1} \mathrm{~V}$ slovenskem vzgojno-izobraževalnem prostoru si strokovnjaki, akademski teoretiki in praktiki še niso povsem enotni, ali na predšolski stopnji govorimo o »nadarjenosti« ali »potenci-
} 
jajo tudi številni strokovnjaki (Bezić 2003; Bloom 1985; Ferbežer 1998; 2002; Gross 1993; Grubb 2008; Hollingworth 1942; Hunt 1961; Nagel 1987; Strmčnik 1995; Žnidar 2016 idr.). Ustrezno razumevanje in spodbujanje otrokovih potencialov $v$ vrtcu in ob vstopu $v$ šolo sta najoptimalnejši prispevek $k$ njegovemu ustreznemu kognitivnemu, afektivnemu in nenazadnje družbenemu razvoju. Pri tem izhajamo iz predpostavke, da najvišjo kakovost na področju vzgoje in izobraževanja lahko dosežemo le takrat, ko se pedagoški delavci zavedajo svoje temeljne odgovornosti pri zgodnjem odkrivanju in poučevanju nadarjenih otrok, poznavanju njihovih sposobnosti in lastnosti ter različnih potreb. Zgodnja identifikacija vodi k ustrezni zgodnji edukaciji in zadovoljitvi otrokovih potreb, interesov, zmožnosti. Nadarjeni otroci imajo namreč primarno pravico do ustreznih izobraževalnih možnosti, ki bodo izzivalno in stimulativno naravnane ter bodo optimalno razvijale njihove potenciale (Kukanja Gabrijelčič in Gorela 2018).

Načrtovan in ustrezno voden prehod iz vrtca $v$ šolo mora temeljiti na stalni komunikaciji s starši, različni dokumentaciji o otroku (anekdotski zapisi, osebna mapa), ustreznemu opazovanju in vključevanju otroka v različne obogatitvene dejavnosti ter dosledni uporabi ocenjevalne lestvice odkrivanja nadarjenega otroka na predšolski stopnji (npr. lestvica Tebbs in Kukanja Gabrijelčič, glej Kukanja Gabrijelčič in Gorela 2018). Pozitivni partnerski odnosi vseh vključenih odraslih in njihova čustvena podpora otroku pa so predpogoj za dobro prilagoditev otroka v šolskem okolju (Ferbežer in Kukanja 2008).

\section{Odkrivanje nadarjenosti na predšolski stopnji}

Strokovnjaki poudarjajo, da sta zgodnje odkrivanje in delo z nadarjenim otrokom izrednega pomena, saj to pomeni ažurno izobraževanje in skrb za intelektualne potrebe nadarjenih otrok, $v$ nasprotnem primeru pa lahko kakršna koli zamuda ali odlašanje privedeta do negativnih čustvenih in vedenj-

alni nadarjenosti«. Tuji strokovnjaki brez zadržkov govorijo o nadarjenem otroku, pri nas pa nemalokrat naletimo na izraz potencialna nadarjenost. V izogib terminološki zmedi avtorici v pričujočem prispevku plastično govoriva o nadarjenosti in z njo povezanih visokih potencialih predšolskega otroka, ki se izkazujejo na produktiven način. Slednje pa ne spremeni dejstva, da lahko o nadarjenem otroku (malčku) načeloma govorimo le v pogojni obliki, saj je to najobčutljivejše obdobje, ko se otrok najhitreje razvija, ko nanj vplivajo številni zunanji (okolijski) ter notranji vplivi/dejavniki ter obdobje, ko ne izvajamo postopka identifikacije z uporabo razvojnopsiholoških pripomočkov ( $v$ smislu merjenja otrokovih intelektualnih sposobnosti, ustvarjalnosti idr.). S terminom »potencialna nadarjenost « sicer zelo jasno nakaževa, da ima otrok na predšolski stopnji visoke potenciale oz. zmožnosti za doseganje visokih dosežkov, da pa z zagotovostjo ne moremo trditi, da bo slednje tudi ustrezno razvil/manifestiral. 
skih posledic pri otroku (Bregant 2012; Ferbežer, Korez in Težak 2008; Rajović 2013; Sutherland 2012). Predšolske nadarjene otroke v literaturi največkrat omenjajo kot "potencialno nadarjene otroke« (Kukanja Gabrijelčič in Gorela 2018), saj zakonska podlaga za delo z nadarjenimi otroki specifično ne izpostavlja predšolske populacije otrok ter uporabe formalnega testiranja IQ, ki je pomembnejše merilo za identifikacijo nadarjenosti otrok. Sklepamo torej, da sta delo in skrb za nadarjene predšolske otroke prepuščena vzgojnemu osebju. Iz slednjega tudi izhaja, da je takšno delo v slovenskih vrtcih bolj izjema kot pravilo (Stritih 2012). Odkrivanje nadarjenih otrok je posebej opredeljeno le za šolske otroke (evidentiranje $v 3$. in 7. razredu, identifikacija in seznanitev ter mnenje staršev $v$ 4. oz. 8. razredu). Za predšolske otroke v slovenskem prostoru ne poznamo enotnega sistema odkrivanja njihove nadarjenosti. Glogovčeva in Žagar (1990) sta za načrtnejše spremljanje otrokovih znakov na predšolski stopnji razvoja ( $v$ fazi evidentiranja) in napredka zapisala navodila, kot so: (i) ugotoviti otrokove najvidnejše prednosti in mu dati priložnost, da se izkaže, pri tem pa opazovati še druge sposobnosti; (ii) pripraviti več različnih dejavnosti in situacij, pri katerih lahko otrok dela sam, $v$ paru ali v skupini, in opazovati spremembe v vedenju; (iii) opazovati otrokovo vedenje $v$ različnih skupinah otrok (mlajših, starejših); (iv) opazovati, kako njegova prisotnost in odsotnost deluje na ostale otroke; (v) opazovati, kaj najraje dela, ko je sam; (vi) opazovati njegove reakcije na različne spodbude v okolju; (vii) postaviti različno zahtevne naloge in zabeležiti rezultate; (viii) opazovati, kateri otrokovi talenti in interesi se kažejo med igro; (ix) omogočiti mu uresničitev pomembnega cilja in opazovati, katere nove kvalitete se bodo pokazale; $(x)$ omogočiti mu, da sledi svojim hobijem in interesom, ker bo le tako lahko pokazal svoje najznačilnejše sposobnosti ali doslednost reakcij v različnih pogojih; (xi) opazovati njegove reakcije v tekmovalnih situacijah; (xii) ugotoviti mnenja drugih (vzgojiteljic, staršev, trenerjev, vrstnikov ipd.) o njem; (xiii) oblikovati čim popolnejšo sliko o otroku, oblikovano na osnovi mnenja drugih in ocene po ocenjevanju.

Pri odkrivanju nadarjenih otrok $v$ predšolskem obdobju je potrebnih veliko izkušenj in uporaba različnih didaktično-metodičnih postopkov ter tehnik, s katerimi pridemo do ustreznih informacij o otroku, njegovem razvoju ter napredku. Ferbežer $(2005,176)$ predstavi tri faze, ki bi jih morali izvajati pri identifikaciji nadarjenih otrok: (1) vprašalnik za starše - inicialni intervjuji; (2) opazovanje otrokovega vedenja pri različnih dejavnostih; (3) formalna ocena (intelektualnega potenciala), npr. Binet-Simonova skala inteligentnosti, Ravenove barvne in progresivne matrice ipd. Najpogostejša težava v povezavi z zgodnjim odkrivanje nadarjenih pa je ustrezna strokovna podkovanost in 
pripravljenost vzgojiteljev na tovrstno delo in izzive (Ferbežer 2002; Hodge in Kemp 2006; Kukanja Gabrijelčič 2015; Kukanja Gabrijelčič in Čotar Konrad 2015; 2016; Pfeiffer in Petscher 2008; Pfeiffer in Jarosewich 2003; Porter 2005; Renzulli idr. 2009), saj imajo ti težave tako pri odkrivanju in prepoznavanju predšolskih otrok, ki kažejo znake nadarjenosti, kot tudi pri zaznavanju in odzivanju na spoznavne in čustvene potrebe otrok.

Ob tem velja izpostaviti posodobljen koncept Strokovna izhodišča posodobitve Koncepta odkrivanja nadarjenih otrok, učencev in dijakov ter vzgojnoizobraževalnega dela z njimi (Zavod Republike Slovenije za šolstvo 2019), v katerem so strokovna izhodišča naravnana tudi na predšolske nadarjene otroke. Strokovna izhodišča posodobitve Koncepta izpostavljajo tudi pomembnost procesnega opazovanja znakov, ki kažejo potenciale za nadarjene predšolske otroke. Preko opazovanja se izboljšuje tudi pozornost strokovnih delavcev na otroke, ki izhajajo iz nespodbudnih primarnih socialnih obdobij: na dvojno izjemne ${ }^{2}$ predšolske otroke in tudi na otroke $z$ visokimi potenciali. Pripomoček za opazovanje in spremljanje, s pomočjo katerega lahko odkrijemo visoke potenciale in jih omenjajo v Strokovnih izhodiščih posodobitve Koncepta (Zavod Republike Slovenije za šolstvo 2019), je predvsem razvojna diagnostika, s pomočjo katere sistematično opazujemo ter spremljamo napredovanje predšolskega otroka $v$ skladu $z$ načeli formativnega spremljanja. Omenjajo tudi naslednje načine oz. pripomočke za prepoznavanje, opazovanje in spremljanje nadarjenih otrok: (i) strukturirani anekdotski zapisi; (ii) protokoli za opazovanje značilnosti, ki kažejo na visoke potenciale mlajših otrok (npr. holistični pristop challenging young children, the Nebraska starry night protocol) (Nebraska Department of Education 2015); (iii) ocenjevalne lestvice za ocenjevanje znakov visokih potencialov otrok (za vzgojitelje) (Kukanja Gabrijelčič in Gorela 2018); (iv) drugi pripomočki, kot je npr. »škatla za radovedne« (angl. curios chest), ki omogoča identifikacijo in prepoznavanje potencialov ter interesov otrok, starih med 4 in 8 let (Zavod Republike Slovenije za šolstvo 2019, 65-66).

V Strokovnih izhodiščih posodobitve Koncepta (Zavod Republike Slovenije

\footnotetext{
${ }^{2}$ Pred več kot tridesetimi leti se je pojavil termin »nadarjeni učenci s posebnimi potrebami« oz. »dvojno izjemni« (angl. gifted handicapped). V tuji literaturi pa zasledimo še izraze double exceptional, twice exceptional in uniquely gifted (angl.). L. Magajna (2007) je v slovenskem prostoru za opis nadarjenih učencev s posebnimi potrebami uporabila besedno zvezo »dvojno izjemni učenci«. Moon in Hall (1988 v Ferbežer in Kukanja 2008) pa pravita, da se dvojna izjemnost otroka kaže kot nadarjenost z različnimi motnjami oz. primanjkljaji, kot so avtizem, govorne napake, slaba koordinacija gibov ter pomanjkljivost v razvoju motorike, odklonsko vedenje, anksioznost, motnje prehranjevanja, slaba koncentracija, hiperaktivnost in specifične učne težave.
} 
za šolstvo 2019) še posebej poudarjajo vlogo pedagoškega koordinatorja, ki ureja sodelovanje s starši, podporo strokovnim delavcem pri opazovanju, diferenciranju in individualiziranju personaliziranih dejavnostih, podporo pri vodenju zapiskov opazovanja otrok ter skrb za koordinacijo dodatnih dejavnosti in izobraževanj za spodbujanje otrok z visokimi potenciali. Vloga vzgojiteljev v vzgojno-izobraževalnih ustanovah pa je v sistematičnem opazovanju otrok in znakov, ki jih kažejo otroci z visokimi potenciali v dejavnostih učenja ter aktivnostih za njihove razvojne potrebe. Vzgojitelj ves čas vzgojnoizobraževalnega procesa vodi listovnik, spremlja in dokumentira otrokov napredek. Poudarjajo, da je to nujno potrebno vsaj leto pred vstopom v šolo. Listovniki so lahko $v$ digitalni obliki ali kot otrokov portfolio (Zavod Republike Slovenije za šolstvo 2019, 67).

\section{Ustvarjanje spodbudnega učnega okolja za nadarjene otroke $\boldsymbol{v}$ vrtcu}

Za ustvarjanje spodbudnega okolja za otroke, ki kažejo visoke potenciale, je priporočljivo: (i) spodbujanje ustvarjalnega mišljenja (Pečjak in Cvetković Lay 2004 v Zavod Republike Slovenije za šolstvo 2019), reševanje problemov (Pečjak in Cvetković Lay 2004 v Zavod Republike Slovenije za šolstvo 2019), razmišljanje, »kaj če«, umetniško izražanje (Marjanovič Umek 2010 v Zavod Republike Slovenije za šolstvo 2019) s podpiranjem otrokove radovednosti in pripravljenosti tvegati, ustvarjalni miselni izzivi (Bucik 2013), povezovanje gibalnega in miselnega razvoja (Rajović 2013), skrb za socialni in čustveni razvoj (Željeznov Seničar idr. 2018 v Zavod Republike Slovenije za šolstvo 2019); (ii) omogočanje čim večje samostojnosti otroka, čim aktivnejše vloge v igri oz. dejavnosti ter sooblikovanja oz. participacije pri izbiri in izvajanju dejavnosti; (iii) izvajanje obogatitvenih programov vrtca: zgodnje učenje tujega jezika, vključevanje $v$ športne in plesne dejavnosti ter glasbeni vrtec, filozofija za otroke, uvajanje šaha v predšolsko obdobje, ki se je izkazalo kot izredna miselna spodbuda za otroke, ki kažejo interes zanj (Željeznov Seničar idr. 2018 v Zavod Republike Slovenije za šolstvo 2019); (iv) personalizacija učnih izzivov na zgornji meji območja bližnjega razvoja predvsem za zgodnje bralce, za predšolske otroke, ki kažejo izrazit interes in talent za glasbo, šport, ples, likovno izražanje, matematiko, konstrukcijske dejavnosti, miselne aktivnosti itd.; (v) dokumentiranje napredovanja otroka s pomočjo videa, avdiozapisa in spremljanje razvoja s pomočjo listovnika (Zavod Republike Slovenije za šolstvo 2019, 68).

\section{Prehod nadarjenega otroka iz vrtca v osnovno šolo}

Prehod iz vrtca v šolo je bil v slovenskem prostoru deležen veliko pozornosti politike, strokovne in laične javnosti $v 90$. letih prejšnjega stoletja, ko je $v$ 
Sloveniji potekala velika konceptualna reforma izobraževalnega sistema (Eurydice Slovenija 2017). V zakonodajnih in strateških dokumentih imamo na nacionalni ravni poudarjena dva vidika prehoda:

1. Povezovanje med institucijami po izobraževalni vertikali, kjer je poudarjeno, da naj vrtec ne dopusti pošolanja kurikula v vrtcu in naj vztraja pri svojih temeljnih specifičnostih. Na tem mestu je poudarjena tudi vloga svetovalne službe, katere posebna skrb je prehod iz vrtca v šolo oz. uvajanje v šolo (glej Strokovni svet Republike Slovenije za splošno izobraževanje 1999b; Zavod Republike Slovenije za šolstvo 2008). Konkretne oblike in načini sodelovanja med vrtcem in šolo se opredelijo v letnem delovnem načrtu (Eurydice Slovenija 2017).

2. Postopek vpisa, vključno z ugotavljanjem pripravljenosti na šolo ter odlogom. $V$ postopku ugotavljanja pripravljenosti lahko šola sodeluje $v$ vrtcem.

V Sloveniji so najpogostejše prakse priprave otrok in staršev na prehod v šolo: pogovori med vzgojiteljico in otrokom o šoli, razvijanje porajajoče in zgodnje bralne pismenosti, razvijanje samostojnosti pri oblačenju in higieni ter obiski šol, srečanja bodočih prvošolcev in staršev v šoli, organizacija umetniških, kulturnih in športnih dogodkov na šoli, kamor povabijo tudi otroke iz vrtca. Iz podatkov študije Eurydice Slovenija (2017) pa ni razvidno, da bi bili pri načrtovanju in izvajanju prehoda iz vrtca v šolo upoštevani predlogi, mnenja in stališča otrok. Sodelovanje s starši v glavnem poteka $v$ obliki samega postopka vpisa, roditeljskih sestankov, ki jih organizirajo vrtci in šole, pa tudi individualnih pogovornih ur v vrtcu in strokovnih srečanj $s$ starši na temo prehoda $v$ šolo.

Prehod mora otrokom primarno zagotavljati kontinuiteto izkušenj v njihovem lastnem učenju, temeljiti mora na skladnosti ključnih odnosov, povezovanju znotraj in med institucijami, vodenju in prenosu ustreznih informacij o otroku in njegovi družini (s soglasjem staršev) ter tesnem sodelovanju staršev in ustreznih strokovnjakov (Zavod Republike Slovenije za šolstvo 2018). Raziskave prehoda otrok iz vrtca v osnovno šolo so $v$ raziskovalnem polju slabo raziskane, še posebej pa to velja za nadarjene otroke (Petani, Kashahu in Miočić 2018). Pomembno je, da je prehod v šolo subtilen in otroku prijazen, komunikacija oz. sodelovanje s starši pa kontinuirano, s pretokom informacij, ki so veljale v vrtcu (Petani, Kashahu in Miočić 2018). Ustrezno uravnoteženo, čustveno stabilno in otroku prijazno, spodbudno okolje namreč vpliva na njegovo socialno in čustveno močno prilagodljivost šolskemu okolju, poveča- 
nje zadovoljstva s šolskim življenjem ter $z$ igro, izobraževanje in socializacijo z drugimi otroki ter odraslimi (Janus 2011). Način prilagajanja nadarjenega otroka ob prehodu iz vrtca $v$ šolo je povezan $z$ različnimi prehodnimi procesi, intelektualnimi izzivi, s čustvenim doživljanjem otroka; gre za njegovo psihosocialno in kulturno prilagajanje kognitivnim, socialnim in čustvenim razsežnostim novega šolskega okolja. Prehod iz vrtca v šolo je bil tako prepoznan kot najobčutljivejše in najtežavnejše obdobje za nadarjenega otroka (Janus 2011; Karnes 1983).

Tudi v slovenski praksi se na prehodu iz vrtca v šolo osredotočamo zgolj na vpisni postopek oz. vpisno dokumentacijo (z osnovnimi podatki o otroku) ter morebitno mnenje pediatra oz. drugih medicinskih delavcev, psihologa oz. pedopsihiatra, ki poda oceno o otroku (npr. težave otrok s posebnimi potrebami ali odlog šolanja). Če poenostavimo, usmerjeni smo zgolj v tradicionalni vidik, ki preučuje in analizira otrokovo pripravljenost na vstop v šolo, načeloma pa se ne ukvarjamo s tem, če in kako je šola pripravljena na vstop nadarjenega otroka.

Tako kot vrtec ima namreč nadaljnjo skrb za razvoj nadarjenosti pri otroku ob prehodu na višjo raven izobraževanja osnovna šola. Naloga vodstva šole je, da svoje strokovne delavce opolnomoči za delo z nadarjenimi učenci pa tudi da o delu in značilnostih učenca seznani starše in širše okolje, ki bi lahko prispevalo $\mathrm{h}$ kakovostnemu razvoju posameznika. Kukanja Gabrijelčičeva (2017) opiše spoznanja, ki naj bi bila vodilo pri pedagoškoraziskovalnem delu z nadarjenimi otroki: pomembna je zgodnja identifikacija nadarjenih na predšolski stopnji in na vseh predmetnih področjih; izobraževanje nadarjenih je potrebno postaviti v širši družbeno-politični kontekst; izhajanje iz »v otroka usmerjenega izobraževalnega programa«; stremenje šole in učitelja $\mathrm{k}$ razvoju ter uporabi učnih metod in tehnik, ki spodbujajo samoregulacijo učenja, ustvarjalno mišljenje, različne pristope učenja, kritičnost, divergentno mišljenje, ustvarjalno izražanje, samostojno odkrivanje in raziskovanje, sodelovalno učenje, skupinsko delo; zagotavljanje spodbudnega, motivacijskega, bogatega in izzivalnega učnega okolja za nadarjene učence; informiranje strokovnih delavcev, sveta šole, sveta staršev in širšega okolja o delu z nadarjenimi; analiza obstoječega stanja o delu z nadarjenimi učenci na šoli; operacionalizacija koordinatorja za delo z nadarjenimi; načrt sprotnega spremljanja uresničevanja ciljev in upoštevanja didaktičnih načel dela z nadarjenimi; informiranje staršev; priprava in ponudba programov za spodbujanje razvoja nadarjenosti v prvi triadi.

Pri prehodu nadarjenega otroka iz vrtca v šolo je še posebej pomembno upoštevati tri temeljna področja: (i) usklajevanje obogatitvenih pristopov in 
nadaljnjega individualiziranega načrta dela med programom vrtca in programom dela z nadarjenim v osnovni šoli; (ii) aktivna participacija otroka in njegove družine (staršev, skrbnikov), šolskega osebja, strokovnega osebja iz vrtca pri prenosu informacij in dokumentacije o nadarjenem otroku; in (iii) neprekinjeno partnerstvo med družino, vrtcem, šolo in skupnostjo (Pierce in Brins 2013 V Petani, Kashahu in Miočić 2018).

Zaradi hitrega razvoja otroka $v$ obdobju zgodnjega otroštva je za maksimalen izkoristek otrokovih potencialov in razvijanje nadarjenosti nujen partnerski odnos vseh vključenih v otrokovo vzgojo in izobraževanje (tj. vodstva vzgojno-izobraževalne institucije, drugih pedagoških in strokovnih delavcev, staršev otrok in nadarjenih otrok).

\section{Starši kot uradni vir prenosa informacij o nadarjenem otroku}

Pri zagotavljanju čim mehkejših in uspešnejših prehodov iz vrtca v šolo je potrebno zagotoviti sodelovanje vseh, ki so soudeleženi v prehodu. Glavni izziv na področju sodelovanja med vrtcem in šolo je prenos informacij o posameznem otroku oz. zaščita otrokovih osebnih podatkov ob prehodu (Eurydice Slovenija 2017).

Pomembno in občutljivo področje je prenos informacij o otroku, saj lahko to naredimo le s pisnim soglasjem staršev, $v$ katerem je opisan natančen namen. Pomembno je, da so starši ob vpisu otroka in drugem sodelovanju z vzgojno-izobraževalno institucijo spodbujeni k temu, da sporočijo (poleg zdravstvenega stanja in morebitnih težav) tudi druga izstopajoča opažanja o otrokovem kognitivnem in/ali afektivnem razvoju, specifičnih talentih, hitreje napredujočem intelektualnem razvoju (hitrejše branje, opismenjevanje, računanje, poznavanje tujega jezika idr.).

Vrtec naj bi torej šoli zagotavljal informacije o otroku, ki bodo $\mathrm{v}$ podporo uspešnemu prehodu (vedno v soglasju s starši), zato je pomembno, da njuno sodelovanje temelji na ustreznem odnosu in pretoku informacij. Prehodi otrok so namreč zelo odvisni od učinkovitega sodelovanja med institucijami in starši ter zahtevajo pravočasno posvetovanje o tej temi, razvojno ustrezno in prijetno vključevanje otrok, zagotavljanje kontinuitete izkušenj otroku ter takšne postopke in prakso, ki spodbujajo občutljivo ravnanje in obvladovanje teh sprememb v dobro otroka (Zavod Republike Slovenije za šolstvo 2018). Vključitev staršev v delo vzgojno-izobraževalnih ustanov prispeva tudi k boljši pripravljenosti otroka za šolo, ob kateri bo bolje razvijal socialnočustvene, bralne in matematične sposobnosti (Lau, Hui in Rao 2011 v Petani, Kashahu in Miočić 2018). Da bi karseda optimalno podprli otrokov razvoj (na mnogoterih področjih), so izrednega pomena vzajemno sodelovanje (šola, 
vrtec, starši), priprava obogatenega kurikuluma, priprava individualiziranega učnega programa ter omogočanje priložnosti za druženje in učenje z vrstniki podobnih sposobnosti.

\section{Opredelitev problema in namen raziskave}

$\checkmark$ teoretičnih opredelitvah navajani strokovnjaki poudarjajo pomen zgodnjega spodbujanja otrokovih potencialov, predvsem z vidika izsledkov sodobnih spoznanj o razvoju možganov, notranje motivacije in ustvarjalnosti $v$ otroštvu. Zgodnje odkrivanje in identifikacija nadarjenosti pomenita tudi pravočasno in ustrezno edukacijo, kakršno koli zamujanje ali odlašanje identifikacije nadarjenosti pa lahko povzroči negativne značajske in čustvene posledice (o tem pišejo npr. Bregant (2012), Ferbežer (2002), Rajović (2013), Sutherland (2012) idr.). Nikjer $v$ teh postopkih pa ne zasledimo odkrivanja nadarjenih predšolskih otrok ter nadaljnjega prenosa pomembnih informacij o otrokovih kognitivnih in afektivnih značilnosti, potrebah in interesih na osnovnošolsko stopnjo, kljub temu, da »Koncept: odkrivanje in delo z nadarjenimi učenci v devetletni osnovni šoli« (Strokovni svet Republike Slovenije za splošno izobraževanje 1999a) predvideva, da se delo z nadarjenimi otroki $v$ šoli začne že $v$ prvi triadi osnovne šole (in sicer v obliki notranje diferenciacije pouka). Zanimalo nas je predvsem, kako se občutljive informacije o otroku, ki jih varuje Zakon o varstvu osebnih podatkov (2007), prenašajo iz vrtca v šolo, od vzgojiteljice do učiteljice.

Študijo smo pripravili na podlagi analize strateških (Ministrstvo za šolstvo in šport 2011; Nacionalni kurikularni svet 1996; Ministrstvo za šolstvo in šport 1999; Strokovni svet Republike Slovenije za splošno izobraževanje 1999a itd.) in zakonodajnih dokumentov (Zakon o organizaciji in financiranju vzgoje in izobraževanja 2007; Zakon o vrtcih 2005; Zakon o osnovni šoli 2006) ter ustreznih poročil, raziskav s področja nadarjenosti na predšolski in šolski stopnji. Poleg tega smo podatke zbrali tudi neposredno v vrtcu, osnovni šoli in v družini nadarjenega otroka. Namen raziskave je na podlagi študije primera raziskati: (i) kako se razlikuje pogled na nadarjenega otroka in delo z njim med vrtcem (vzgojiteljem) in šolo (učiteljem), (ii) kakšno je sodelovanje med vzgojiteljem in učiteljem ob prehodu nadarjenega otroka iz vrtca v šolo ter (iii) kakšno vlogo in pomen imajo starši pri spremljanju, napredku in prehodu nadarjenega otroka iz vrtca v šolo.

\section{Metodologija}

Pri kavzalno-neeksperimentalni raziskavi smo uporabili kvalitativni pristop z deskriptivno metodo raziskovanja. Glavni sodelujoči v raziskavi je nadar- 
jen otrok, ki ga bomo zaradi varstva osebnih podatkov (GDPR) poimenovali Matej.

Pri študiji primera smo izhajali iz različnega gradiva: splošne ocene otrokovega funkcioniranja (starši, vzgojiteljica in učiteljica), analize celostne ocene otrokovega funkcioniranja, kontrolne lestvice, pregleda obstoječe dokumentacije, analize vzpostavitve domačega, vrtčevskega in šolskega učno spodbudnega okolja, razgovora z vzgojiteljico (polstrukturiran intervju), razgovora s starši (nestrukturiran intervju), razgovora $z$ učiteljico nadarjenega otroka (polstrukturiran intervju).

\section{Rezultati z razpravo}

\section{Pogled na nadarjenega otroka in delo z njim s strani vrtca (vzgojitelja) in šole (učitelja)}

Otrok je že ob vstopu v vrtec kazal znake potencialne nadarjenosti, ${ }^{3}$ intelektualne nadpovprečnosti, saj je kljub temu, da je bil v skupini najmlajši, od večine izstopal v več osvojenih kompetencah oz. veščinah in različnih področjih razvoja. Vzgojiteljica se je trudila, da bi njegove potrebe čim bolj zadovoljevala: nudila mu je čas za pogovor, dodatne naloge, ko je zanje pokazal interes.

Ob pogovoru z vzgojiteljico smo ugotovili, da je otroka prepoznala kot nadarjenega in da mu je tudi nudila pozornost, dodatne zadolžitve, želela je spoznati njegove potrebe, z njim se je veliko pogovarjala. Vzgojiteljica je relativno hitro odkrila otrokova močna področja in z njim krepila šibkejša. Zavedala se je otrokovih nadpovprečnih sposobnosti, kljub temu pa ga ni socialno izolirala z individualnimi zadolžitvami, temveč je sodeloval pri vseh skupinskih dejavnostih, kjer pa je imel zahtevnejše zadolžitve (glavna vloga pri dramatizaciji, branje navodil in podobno). Vzgojiteljica je redno sodelovala $s$ starši pa tudi zelo spodbudno vplivala na otrokovo počutje $v$ času bivanja $v$ vrtcu, saj starši ne poročajo o večjih čustvenih in vedenjskih težavah iz ti-

\footnotetext{
${ }^{3}$ Predšolski nadarjeni otroci so v strokovni literaturi največkrat pojmovani kot »potencialno« nadarjeni otroci. Opredelitev besede pomeni »možnost zmožnosti« predšolskega otroka, torej »možnosti, da nekaj zmore«. Avtorji govorijo o t. i. potencialni nadarjenosti predšolskega otroka, »ki izkazuje nekatere značilnosti nadarjenosti v zgodnjem otroštvu, med predšolskim obdobjem in na začetku šolanja, ni pa zanesljiv podatek, da bo otrok tudi kasneje v svojem življenju dejansko nadarjen « (Kukanja Gabrijelčič in Gorela 2018, str. 21). Nadarjenost predšolskega otroka pojmujemo kot "potencialno nadarjenega« tudi zato, ker se v predšolskem obdobju ne izvaja formalnega testiranja IQ-ja, in sicer zaradi hitre rasti in razvoja možganov. Majhni otroci se težko osredotočijo na takšne formalne načine preizkusov, zanje so prezahtevni. Upoštevati moramo tudi dejstvo, da so inteligenčne sposobnosti otrok večplastne in presegajo ozko oceno, ki jo nudijo IQ-testi (Kukanja Gabrijelčič in Čotar Konrad 2016).
} 
stega obdobja. ${ }^{4}$ Pri razgovoru z vzgojiteljico pa tudi iz dokumentiranega dela z otrokom (osebna mapa, anekdotski zapisi) ugotavljamo, da je bila vzgojiteljica neobremenjena z zunanjimi dejavniki, ki bi njeno delo $z$ otrokom omejevali ali usmerjali v okviru dnevne rutine. Delovala je po lastnem instinktu in iskala različne didaktično-metodične strategije pri aktivnemu vključevanju otroka v učni proces. ${ }^{5}$

\section{Sodelovanje med vzgojiteljem in učiteljem ob prehodu nadarjenega otroka iz vrtca $v$ šolo}

Prehod v šolo je bil za otroka in njegovo družino zelo težaven. Kljub temu, da so starši šoli posredovali informacijo o otrokovih nadpovprečnih sposobnostih in načinu dela z njim v vrtcu, se v šoli ni dobro počutil. Značilno zanj je bilo odklonsko vedenje, s katerim je izkazoval čustveno (npr. tiki) in intelektualno stisko, saj njegove potrebe niso bile zadovoljene. Prihajajo je do agresivnih reakcij (konflikti med sošolci), ki jih ni mogel obvladati. Skozi šolsko leto se je zdelo, da je šoli mar le za to, da je zadoščeno zakonskim podlagam pri delu z otrokom, kar je opazno iz globalne ocene otrokovega delovanja s strani učiteljic (navajajo zgolj doseganje standardov znanja za 1. razred, ne poznajo pa otrokovih ostalih nadpovprečnih sposobnosti, osebnostnih lastnosti, želja, potreb). ${ }^{6}$ Ugotovili smo, da so se šolska svetovalna služba in učiteljice sklicevale na pravilnike in zakone, ki omejujejo oz. celo prepovedujejo delo z nadarjenimi otroki $v$ 1. razredu kakor tudi predmetno akceleracijo, ki je bila sprva dogovorjena za Mateja. Pričakovanje otroka in staršev, da bo šola pote-

\footnotetext{
${ }^{4}$ Nadarjeni v medosebni inteligentnosti so praviloma psihološko dobro prilagojeni. V določenih primerih pa se lahko opazijo težave $v$ empatičnih in komunikacijskih sposobnostih ter sposobnostih vplivanja na druge (Ferbežer in Kukanja 2008). Nadarjenim otrokom čustvene in vedenjske težave povzroča predvsem asinhronost $v$ razvoju. Večja kot je asinhronost v razvoju različnih področij pri otroku, bolj je ta podvržen razvoju čustveno-socialnih in vedenjskih težav (Morawska in Sanders 2009).

${ }^{5}$ Stritih (2012) opozarja, da je treba vse vzgojitelje opremiti z znanji in veščinami, če želimo na izvedbeni ravni vsem otrokom, tudi tistim z večjimi potenciali, omogočiti možnosti in pogoje za njihovo optimalno učenje ter razvoj. Kroflič (1994) meni, da vzgojiteljice v vrtcu sicer zmorejo prepoznati nadarjenega otroka, težave pa imajo s tem, kako zadovoljiti njegove potrebe in ga ustrezno socialno integrirati, ne da bi pri tem trpel njegov pospešeni razvoj. Kukanja Gabrijelčičeva in Čotar Konradova (2016) zato navajata nekatere predloge, s katerimi bi slovenski šolski sistem uredil področje nadarjenih otrok.

${ }^{6}$ Opazne so vrzeli na področju vzpostavitve ključnih elementov spodbudnega socialnega učnega okolja v šoli, ki se oblikuje predvsem preko odnosov med učitelji in učenci ter med učenci samimi. V ospredju odnosov so občutek fizične in socialno-emocionalne varnosti, tolerantnost in socialna pravila v šoli ter spoštovanje različnosti, občutek vključenosti in povezanosti, učiteljeva prepričanja, stališča, komunikacijski slog in upravljanje razreda (Bascia 2014).
} 
šila njegovo radovednost, je zamrlo. Matej je postajal frustriran, $v$ domačem okolju pa vse zahtevnejši. Zahteval je, da starši zadovoljijo njegove intelektualne potrebe, doma je bil nemiren, iz šole je prihajal nejevoljen, nenehno je zahteval pozornost, odklanjal je šolsko delo in zahteval druge zadolžitve. Sodelovanja med vrtcem in šolo ni bilo, informacije o otrokovih nadpovprečnih sposobnostih, značilnostih na kognitivnem in afektivnem področju so prenesli otrokovi starši. ${ }^{7} \vee$ šoli za otroka niso pripravili obogatenega kurikuluma ali prilagojenega, individualiziranega programa. ${ }^{8}$ Otrok in starša navajajo, da je dobival zgolj dodatne naloge, ki se niso navezovale na njegove želje, potrebe, temveč so bile le zaposlitev, da je bil v razredu »mir« (npr. dodatni računi pri uri matematike, ponovno branje nezahtevnega besedila). Šlo je torej zgolj za ponavljanje obstoječega znanja, brez možnosti nadgradnje, izzivalnih miselnih nalog, spodbujanja ustvarjalnosti. Učiteljice so navajale, da mora Matej upoštevati pravila in navodila, ki so veljala za vse otroke v razredu. Ob verbalnem konfliktu so se z njim želele pogovoriti, kar sicer ni bila vedno dobra praksa, saj otrok ni bil vedno pripravljen na pogovor. Takrat so ga izločile iz skupine, kar je bila v tistem trenutku sicer za skupino dobra rešitev, vendar ne zanj.

\section{Vloga in pomen staršev pri spremljanju, napredku in prehodu nadarjenega otroka iz vrtca $v$ šolo}

Starša sta bila pozorna na to, da sta otroku dajala karseda veliko miselnih izzivov. Odgovarjala sta na mnogotera zahtevna vprašanja, kupovala knjige, ki otroka zanimajo, z njim ustvarjala. ${ }^{9}$ Mateju sta nudila veliko različnih mate-

\footnotetext{
${ }^{7}$ Raziskave (Cross in Cross 2011; Hargrove 2010) opozarjajo, da je za kognitivni in psihofizični razvoj nadarjenega učenca ustrezno socialno učno okolje izjemno pomembno, saj imajo lahko nadarjeni učenci, ki so intelektualno napredni, asinhron razvoj na socialnem in čustvenem področju (Hargrove 2010). Nadarjeni učenec doživlja velike izzive v odnosih z vrstniki in v odnosih z odraslimi (Cross in Cross 2011). Vključevanje nadarjenih učencev v dejavnosti, kjer so lahko optimalno izboljšali svoje kognitivne sposobnosti, ustvarjalnost, sposobnost reševanja problemov, pa je vplivalo na njihovo višjo samopodobo (Cross in Cross 2011). Prenos informacij na kognitivnem in konativnem področju je torej ključen, če se želimo izogniti morebitnim otrokovim frustracijam in težavam.

${ }^{8}$ Evalvacije (Colangelo, Assouline in Gross 2004) so ugotavljale vpliv izobraževalnega kurikuluma in razvrščanja učencev glede na sposobnosti ter dosežke nadarjenih učencev. Avtorji ugotavljajo, da so imeli tisti nadarjeni učenci, ki so sodelovali v obogatitvenem programu, višje učne dosežke ter boljši odnos do učenja kot tisti učenci, ki v njem niso sodelovali (Reis idr. 2007).

${ }^{9}$ Starši nadarjenih otrok se pogosto srečujejo s težavnim vedenjem svojih otrok, ki od njih zahteva večjo angažiranost za oblikovanje konstantnih stimulacij za otroka in umerjanje njegovega čustvenega vedenja ter doživljanja. Za nemoteno funkcioniranje potrebujejo nadarjeni otroci venomer visoke stimulacije iz okolja (Porter 2005).
} 
rialov, pripomočkov za ustvarjanje. Trudila sta se ustvarjati čim optimalnejše in spodbudnejše okolje za otrokov razvoj, kljub temu pa ga učiti, da ni sam na svetu in da se mora vseeno držati pravil, ki jih družba narekuje, v tolikšni meri, da s svojimi dejanji ali aktivnostmi ne ogroža ali škodi drugim oz. sebi. Staršema se zdi izrednega pomena tudi redno sodelovanje s šolo, ki jo otrok obiskuje, čeprav za njune ideje in pobude ni imela posluha. ${ }^{10}$ Velikokrat sta se čutila nemočna pri zadovoljevanju otrokovih potreb, pri uresničevanju njegovih želja in opolnomočenju sebe z znanjem o tem, kaj otrok potrebuje in $v$ kolikšni meri mu te potrebe omogočiti, pri vsem tem pa sta čutila še nemoč v šolskem prostoru, kjer z otrokom nista bila sprejeta, razumljena. Starša sta navedla, da je bil prehod iz učno spodbudnega okolja in čustvene podpore vzgojiteljice $v$ šolo preveliko breme za otroka. Poznalo se je na upadu motivacije, kognitivnih konfliktih, ki jih je doživljal, čustvenih in vedenjskih težavah, samopodobi. Še posebej pomembna in nazorna je diskrepanca, ki se kaže v otrokovi dokumentaciji, kjer je zapisana globalna ocena njegovega delovanja s strani vzgojiteljice in učiteljice $v$ 1. razredu osnovne šole. Ob primerjavi ocen ugotavljamo, da je veliko področij, kjer je otrok dobro in izredno deloval, in da je bil njegov razvoj izstopajoč v primerjavi z večinsko populacijo vrstnikov, a se $v$ šolskem okolju ni opazil. Ob podrobnejšem pregledu vzgojiteljičine globalne ocene in ob pogovoru z njo smo ugotovili, da je bila vzgojiteljica v vrtcu veliko pozornejša na dečkovo počutje, na njegovo vedenje $v$ smislu socialnega vključevanja v skupino in na čustvovanje, vzgojiteljičina ocena je bila manj storilnostno in bolj individualno ter razvojno naravnana, medtem ko se globalna ocena učiteljice ves čas osredotoča večinoma na standarde znanja, ki jih opredeljuje učni načrt za prvi razred osnovne šole. Učiteljice niso iskale otrokovih splošnih interesov in potreb izven okvirov šolskega okolja." Opazili smo tudi, da je vzgojiteljica dečka na podlagi njego-

${ }^{10}$ Colangelo in Dettman (1982 v Ferbežer in Kukanja 2008) sta razvila svetovalni model, ki obsega štiri različne tipe sodelovanja med šolo in starši nadarjenega otroka, kjer izpostavljamo predvsem kooperacijo (sodelovanje) med starši nadarjenega učenca in šolo. Model sloni na prepričanju, da mora biti šola dejavna na področju izobraževanja nadarjenega otroka. Tovrstno sodelovanje je obojestransko in stremi k odprtemu pretoku informacij o otrokovem razvoju, napredku ter potrebah $v$ šoli in doma. Na takšen način imajo nadarjeni otroci večje možnosti za optimalni razvoj, saj izmenjava informacij med starši in šolo pripomore k specializiranim pristopom in možnosti nadgradnje ter spreminjanju in razvijanju izobraževalnih programov. Sodelovanje sodi med najpomembnejše člene otrokovega življenja in je izredno učinkovito za razvoj izjemnih sposobnosti preko odprtega pretoka in izmenjave informacij o potrebah nadarjenega otroka ter posledično pripravo posebnega individualiziranega programa, ki jih bo poskušal v največji meri zadovoljiti.

${ }^{11}$ Pri vzajemnem delovanju tipa 2 (konflikt) je v ospredje postavljeno navzkrižje med aktivnimi starši in pasivno šolo, ki ni dovolj dejavna na področju izobraževanja in razvoja otrokovih iz- 
vih interesov vključevala $v$ dejavnosti za vse, le da mu je ob tem zastavljala zahtevnejše izzive, $v$ šoli pa takšne oblike učne diferenciacije ni bil deležen. Iz ocene učiteljic in iz pogovora z njima ne zaznamo, da bi imel otrok v šoli spodbudno učno okolje (fizično, socialno, didaktično ali kurikularno), kar je v njem postopoma demotiviralo željo po novih spoznanjih in učnem delu.

Na podlagi zgoraj zapisanih ugotovitev in teoretičnih spoznanj ugotavljamo, da značilnosti, ki jih imajo nadarjeni otroci na predšolski stopnji in kasneje, ob prehodu v osnovno šolo, nikakor ne smemo prezreti, saj neustrezno okolje ali neustrezna obravnava lahko privedeta do izgube motivacije ali celo do vedenjskih in psihosomatskih težav (Bloom 1985; Ferbežer 1998; 2002; Gross 1993; Grubb 2008; Hollingworth 1942; Hunt 1961; Nagel 1987). Tudi nadarjeni otroci za uspeh in razvoj svojih potencialov potrebujejo spodbudno učno okolje in predvsem zadovoljitev intelektualnih potreb, ki temeljijo predvsem na personalizaciji in personifikaciji učenja, pristnih medsebojnih odnosih ter visokih pričakovanjih oz. stremljenju k odličnosti (Hopkins 2007). Pomembno je, da vzgojiteljice, učiteljice in tudi starši zgodaj prepoznajo otrokovo nadarjenost, da se ta kasneje ne izgubi v povprečju. To pomeni, da bi moralo vzgojno osebje, ki je otroka spremljalo v predšolskem obdobju, imeti dovoljenje, odgovornost in obvezo, da osebno mapo z značilnostmi otroka preda šolskemu osebju (učiteljem in svetovalni službi), saj se morebitna dobra praksa ob prehodu med ravnmi šolanja lahko nadaljuje. Predvsem je pomembno, da so vzgojitelji in razredni učitelji ustrezno pedagoško-psihološko in didaktično-metodično usposobljeni za odkrivanje in delo $z$ nadarjenim otrokom. Na tem mestu izpostavljamo predvsem: (i) poznavanje postopkov za evidentiranje nadarjenih otrok $v$ vrtcu in prvem triletju osnovne šole; (ii) ustrezno strokovno in praktično usposobljenost pri odkrivanju nadarjenih otrok, njihovih lastnosti in potreb; (iii) poznavanje oblik, metod in tehnik dela z nadarjenimi; (iv) sodelovanje s starši, ki lahko zajema izobraževanje staršev, svetovanje staršem, konzultacije itd.; (v) redno spremljanje napredka otrok; (vi) vpeljevanje kreativnih pristopov $\mathrm{k}$ šolskemu delu.

jemnih sposobnosti (Colangelo in Dettman 1982 v Ferbežer in Kukanja 2008). Tako so na eni strani starši prepričani, da njihov otrok nujno potrebuje prilagojene programe, ki bodo zadostili vsem njegovim potrebam in sposobnostim, na drugi strani pa je šola, ki je zadovoljna s trenutnim šolskim programom, ki je uspešen na področju zadovoljevanja potreb vseh učencev, vključno z nadarjenimi. Do konflikta lahko prihaja predvsem zaradi neupoštevanja specifičnih in izobraževalnih potreb nadarjenega otroka in prepričanja šole, da so na tem področju straši prezahtevni in preobčutljivi. Starši pa lahko delujejo izredno napadalno in vztrajno, saj želijo doseči posluh za problemsko naravnanost in odpravo nezanimanja, nezadovoljevanja in zanemarjanja nadarjenega otroka v šoli. Vrsta 2 je zagotovo najzahtevnejši in najproblematičenejši vidik sodelovanja med starši in šolo (Colangelo in Dettman 1982 v Ferbežer in Kukanja 2008). 


\section{Sklep}

Ključno vprašanje, ki ga osvetljuje tudi študija primera, se nanaša na tegobo, kako doseči kontinuiteto prenosa znanj in informacij na prehodu iz vrtca $v$ osnovno šolo. Praksa v slovenskem prostoru namreč dokazuje potrebo po izboljšanju usposobljenosti strokovnega osebja za ustrezno didaktičnometodično delo z nadarjenimi; slednje se nanaša tudi na delo $z$ nadarjenimi $v$ osnovni šoli. Celotna priprava otroka na šolo torej temelji tudi na ustreznem sodelovanju med družinami in dvema izobraževalnima sistemoma.

Posebno pozornost je treba nameniti predvsem delu z nadarjenimi otroki v procesu prehoda iz vrtca v šolo. Za razliko od normativnega otroka sta lahko dojemanje in pričakovanje nadarjenega povsem drugačna $v$ odnosu do učitelja in šole, $v$ katero vstopa. Menimo, da je potrebno strategijo prehoda nadarjenega otroka iz vrtca v šoli razviti na tri načine: (1) priprava in pomoč družinam za uresničevanje temeljnih otrokovih pravic v procesu šolanja; (2) organizacija dela vrtca, da v svoj delovni načrt vključi pravico otroka do realizacije njegovih nadpovprečnih sposobnosti s holističnim pristopom in z upoštevanjem njegovih temeljnih kognitivnih ter afektivnih značilnosti, potreb, želja in interesov; (3) stalnost strokovnega izobraževanja in skrbi za profesionalno kontinuiteto $v$ vrtcu in šoli s področja nadarjenosti.

Strokovna in pedagoška kontinuiteta sta sicer zelo dobro zagotovljeni v Izhodiščih kurikularne prenove (Nacionalni kurikularni svet 1996), kjer je eno izmed ključnih načel tudi vertikalna in horizontalna usklajenost programov in učnih načrtov. Glavna skupna točka je, da gre v obeh primerih za učnociljno in procesno-razvojno naravnane kurikulume oz. programe. Tudi področja dejavnosti ( $v$ vrtcu) oz. predmeti ( $v$ osnovni šoli) nakazujejo določeno raven kontinuitete (Eurydice Slovenija 2017). Ugotovitve naše študije primera pa kažejo, da skupno delo razrednega učitelja in vzgojitelja v prvem razredu ni pripeljalo do boljše pedagoške kontinuitete (torej do vpliva vrtca na šolo), čeprav je bil to eden izmed pomembnih ciljev reformnih ukrepov (Bahovec in Bregar Golobič 2004 v Eurydice Slovenija 2017), saj je v prvih razredih veliko sedenja, poslušanja, manj igre in sodelovalnega učenja ter aktivne participacije otrok.

Tematika prehoda iz vrtca $v$ šolo je bila $v$ strokovnih, političnih in laičnih krogih izjemno aktualna $v 90$. , ko je pri nas potekala konceptualna reforma izobraževalnega sistema (Eurydice Slovenija 2017). Vendar ugotavljamo, da je bila po začetnem obdobju aktualnosti kasneje $v$ veliki meri spregledana. To še posebej velja za nadarjene otroke, za katere bi lahko s pomočjo nacionalnih in tujih poglobljenih kvalitativnih ter kvantitativnih analiz oblikovali 
smernice za nadaljnje delo na tem zapostavljenem področju. Pomembni so predvsem usposabljanje strokovnih delavcev za delo z nadarjenimi otroki, okrepitev sodelovanja med vrtcem in šolo, ustrezen prenos ne zgolj osebnih podatkov, temveč informacij o otrokovih značilnostih s pomočjo različne dokumentacije o otroku (osebne mape, anekdotski zapisi, opazovalne in ocenjevalne lestvice, otrokovi izdelki idr.). Morda bi veljajo več pozornosti nameniti tudi pedagoški kontinuiteti strokovnih in pedagoških delavcev s področja odkrivanja ter dela z nadarjenimi učenci. S tem bi lahko zagotovili profesionalno, pedagoško in razvojno kontinuiteto, kar bi vzpostavilo priložnosti za vzpostavitev ustreznega spodbudnega učnega okolja za nadarjene otroke in predvsem ustrezno načrtovanje sprememb $v$ prihodnje. Kajti s humanističnega in z družbenoodgovornega vidika smo namreč vsi soodgovorni za razvoj mladih potencialov, talentov in nadarjenih posameznikov - za njihovo lastno samouresničitev in naš skupni gospodarski ter družbeni napredek.

\section{Literatura}

Bahovec, E. D., in K. Bregar Golobič. 2004. Šola in vrtec skozi ogledalo. Ljubljana: DZS.

Bascia, N. 2014. The School Context Model: How School Environments Shape Students Opportunities to Learn. Toronto: People for Education; Ottawa: Canadian Electronic Library.

Bezić, T. 2003. »Odkrivanje in delo z nadarjenimi učenci v devetletni osnovni šoli.«V Nadarjeni - izkoriščen ali prezrt potencial, ur. M. Blažič, 20-43. Novo mesto: Slovensko združenje za nadarjene Novo mesto.

Bloom, B. 1985. Developing Talent in Young People. New York: Ballantine.

Bregant, T. 2012. »Razvoj, rast in zorenje možganov.« Psihološka obzorja 21 (2): 51-60.

Bucik, V. 2013. »Pomoč psihologa vzgojiteljem in učiteljem pri delu z nadarjenimi: nekaj izhodišč in priporočil.« V Podpora psihologa učiteljem in vzgojiteljem pri delu z nadarjenimi: zbornik posvetovanja, ur. M. Juriševič in P. Gradišek, 9-26. Ljubljana: Pedagoška fakulteta.

Colangelo, N., in D. F. Dettmann. 1982. »A Review of Reserch on Parents and Families of Gifted Children." Exceptional Children 50 (1): 20-27.

Colangelo, N., S. Assouline in M. Gross. 2004. A Nation Deceived: How Schools Hold Back America's Brightest Students. lowa City, IA: The University of lowa.

Cross, T. L., in J. R. Cross. 2011. "Social and Emotional Development of Gifted Students.« Gifted Child Today 40 (3): 178-182.

Eurydice Slovenija. 2017. »OECD prehodi: pregled politik in praks izobraževalnih sistemov na področju prehoda otrok iz vrtca v šolo.« https://www .eurydice.si/novice/tema-meseca/oecd-prehodi-pregled-politik-in-praks -izobrazevalnih-sistemov-na-podrocju-prehoda-otrok-iz-vrtca-v-solo/. 
Ferbežer, I. 1998. »Identifikacija in razvijanje nadarjenosti.« V Nadarjeni, šola, šolsko svetovalno delo, ur. T. Bezić, 33-66. Ljubljana: Zavod Republike Slovenije za šolstvo.

- 2002. Celovitost nadarjenosti. Nova Gorica: Educa.

. 2005. »Dabrowski - teorija pozitivne dezintegracije.« Pedagoška obzorja 20 (1): 42-52.

Ferbežer, I., in M. Kukanja. 2008. Svetovanje nadarjenim učencem. Ljubljana: Zavod Republike Slovenije za šolstvo.

Ferbežer, I., I. Korez in S. Težak. 2008. Nadarjeni otroci. Radovljica: Didakta.

Glogovec, Z., in D. Žagar. 1990. Nadarjeni otroci v vrtcu. Ljubljana: Zavod Republike Slovenije za šolstvo.

Gross, M. U. M. 1993. Exceptionally Gifted Children. New York: Routledge.

Grubb, M. 2008. An Examination of the Experiences of Gifted Preschool and Primary Age Children. Melbourne: RMIT University, School of Education.

Hargrove, K. 2010. »If I Had Only Known ...« Gifted Child Today 33 (1): 14-15.

Hodge, K. A., in C. R. Kemp. 2006. »Recognition of Giftedness in the Early Years Of School: Perspectives of Teachers, Parents and Children. "Journal for the Education of the Gifted 30 (2): 164-204.

Hollingworth, L. S. 1942. Children above 180 IQ Stanford-Binet: Origin and Development. Yonkers, NY: World Book.

Hopkins, D. 2007. Every School a Great School: Realizing the Potential of System Leadership. New York: Open University Press.

Hunt, J. M. 1961. Intelligence and Experience. New York: Ronald.

Janus, M. 2011. »Transition to School.« V Transitions to Early Care and Education: International Perspectives on Making Schools Ready for Young Children, ur. D. A. M. Laverick in M. R. Jalongos, 177-189. Dordrecht: Netherlands.

Juriševič, M. 2011. »Vzgoja in izobraževanje nadarjenih.«V Ministrstvo za šolstvo in šport, Bela knjiga o vzgoji in izobraževanju v Republiki Sloveniji, 329-345. Ljubljana: Ministrstvo za šolstvo in šport.

Karnes, B. 1983. »The Challenge in The Underserved.« V The Underserved: Our Young Gifted Children, ur. M. B. Karnes, 11-27. Reston, VA: The Council for Exceptional Children.

Kroflič, R. 1994. »Evalvacija visokošolskega kurikuluma kot sestavni del planiranja."Sodobna pedagogika 45 (5-6): 36-46.

Kukanja Gabrijelčič, M. 2015. Nadarjeni in talentirani učenci: med poslanstvom in odgovornostjo. Koper: Annales.

- 2017. Poučevanje nadarjenih učencev v osnovni šoli. Koper: Založba Univerze na Primorskem.

Kukanja Gabrijelčič, M., in S. Čotar Konrad. 2015. »Teacher Professional Qualifications and Attitudes Toward Gifted and Talented Students. V Educational Sciences in Postmodernity, ur. M. Krajnčan, 47-72. Herzogenrath: Shaker.

—. 2016. »Izzivi in težave na področju odkrivanja in dela z mlajšimi nadar- 
jenimi otroki.« V Nadarjeni in talentirani predšolski otrok, ur. M. Željeznov Seničar, 28-39. Ljubljana: MIB.

Kukanja Gabrijelčič, M., in K. Gorela, K. 2018. Nadarjenost na predšolski stopnji. Koper: Založba Univerze na Primorskem.

Lau, E. Y. H., H. Li in N. Rao. 2011. »Parental Involvement in Children's Readiness for School in China.« Educational Research 53 (1): 95-113.

Magajna, L. 2007. »Prepoznavanje in razumevanje nadarjenih učencev s specifičnimi motnjami učenja." V Učenci s specifičnimi učnimi težavami: skriti primanjkljaji - skriti zakladi, ur. G. Reid, M. Kavkler, M. Košak Bauder in L. Magajna, 168-180. Ljubljana: Društvo Bravo - društvo za pomoč otrokom in mladostnikom s specifičnimi učnimi težavami.

Marjanovič Umek, L., ur. 2010. Otrok v vrtcu:priročnik h kurikulu za vrtce. Maribor: Obzorja.

Ministrstvo za šolstvo in šport. 1999. Kurikulum za vrtce: predšolska vzgoja v vrtcih. Ljubljana: Ministrstvo za šolstvo in šport in Zavod Republike Slovenije za šolstvo.

_. 2011. Bela knjiga o vzgoji in izobraževanju v Republiki Sloveniji. Ur. J. Krek in M. Metljak. Ljubljana: Ministrstvo za šolstvo in šport.

Moon, S. M., in A. S. Hall. 1998. »Family Therapy with Intellectually and Creatively Gifted Children." Journal of Marital and Family Therapy 24:59-80.

Morawska, A., in M. R. Sanders. 2009. »Parenting Gifted and Talented Children.» Gifted Child Quaterly 53 (3): 163-173.

Nacionalni kurikularni svet. 1996. Izhodišča kurikularne prenove. Ljubljana: Nacionalni kurikularni svet.

Nagel, W. 1987. Odkrivanje in spodbujanje nadarjenih otrok: svetovalec za starše in učitelje. Prev. L. Petrovič. Ljubljana: Državna založba Slovenije.

Nebraska Department of Education. 2015. Procedures for the Identification of High-Ability Learners. Lincoln, NE: Nebraska Department of Education.

Pečjak, V., in J. Cvetković Lay. 2004. Možeš i drukčije: priručnik s vježbama za poticanje kreativnog mišljenja. Zagreb: Alinea.

Petani, R., L. Kashahu in M. Miočić. 2018. »Gifted Children and the Transition from Kindergarten to Elementary School.« V ICER/2018 Proceedings, ur. L. Gómez Chova, A. López Martínez in I. Candel Torres, 10082-10090. Valencia: IATED.

Pfeiffer, S. I., in T. Jarosewich. 2003. Gifted Rating Scales. San Antonio, TX: The Psychological Corporation.

Pfeiffer, S., in Y. Petscher. 2008. »ldentifying Young Gifted Children Using the Gifted Rating Scales-Preschool/Kindergarten Form. « Gifted Child Quarterly 52 (1): 19-29.

Pierce, D. C., in A. D. Bruns. 2013. »Aligning Components of Recognition and Response to intervention to improve Tarnsition to Primary School.« Early Childhood Education Journal 14:347-354. 
Porter, L. 2005. Gifted Young Children:A Guide for Teachers and Parents. Berkshire: Open University Press.

Rajović, R. 2010. NTC sistem učenja:metodički priručnikza vaspitače. Vršac: Visoka škola strukovnih studija za obrazovanje vaspitača »Mihailo Palov«.

- 2013. IQ otroka - skrb starša. Ljubljana: Mensa Slovenija.

Reis, S. M., D. B. McCoach, M. Coyne, F. J. Schreiber, R. D. Eckert in E. J. Gubbins. 2007. »Using Planned Enrichment Strategies with Direct Instruction to Improve Reading Fluency, Comprehension, and Attitude toward Reading: An Evidence-Based Study." The Elementary School Journal 108 (1): 3-23.

Renzulli, J. S., D. Siegle, S. M. Reis, M. K. Gavin in R. E. S. Reed. 2009. »An Investigation of the Reliability and Factor Structure of Four New Scales for Rating the Behavioral Characteristics of Superior Students." Journal of Advanced Academics 22 (1): 84-108.

Stritih, B. 2012. »Nadarjeni predšolski otroci - kaj se dogaja z njimi v javnih vrtcih?« V Posvetovanje Vloga psihologa v vzgoji in izobraževanju nadarjenih, ur. M. Juriševič in B. Stritih, 97-106. Ljubljana: Pedagoška fakulteta.

Strmčnik, F. 1995. »Skrb za razvoj nadarjenih učencev.« Vzgoja in izobraževanje 33 (2): 13-17.

Strokovni svet Republike Slovenije za splošno izobraževanje. 1999a. »Koncept: odkrivanje in delo z nadarjenimi učenci v devetletni osnovni šoli.« https:// www.zrss.si/zrss/wp-content/uploads/koncept-dela-z-nadarjenimi -ucenci.pdf.

_. 1999b.Programske smernice: svetovalna služba $v$ osnovni šoli. https:// www.gov.si/assets/ministrstva/MIZS/Dokumenti/Osnovna-sola/Ucni -nacrti/Drugi-konceptualni-dokumenti/Programske_smernice_za _svetovalno_sluzbo_v_osnovni_soli.pdf.

Sutherland, M. 2012. Gifted and Talented in the Early Years: Practical Activities for Children aged 3 to 6. 2. izd. London: SAGE.

Zakon o organizaciji in financiranju vzgoje in izobraževanja (ZOFVI-UPB5). 2007. Uradni list Republike Slovenije, št. 16. https://www.uradni-list.si/1/ objava.jsp?sop=2007-01-0718.

Zakon o osnovni šoli (ZOsn-UPB3). 2006. Uradni list Republike Slovenije, št. 81. https://www.uradni-list.si/1/objava.jsp?sop=2006-01-3535.

Zakon o varstvu osebnih podatkov (ZVOP-1-UPB1). 2007. Uradni list Republike Slovenije, št. 94. https://www.uradni-list.si/1/objava.jsp?sop=2007-01 $-4690$.

Zakon o vrtcih (ZVrt-UPB2). 2005. Uradni list Republike Slovenije, št. 100. https:// www.uradni-list.si/1/objava.jsp?sop=2005-01-4349.

Zavod Republike Slovenije za šolstvo. 2008. Programske smernice: svetovalna služba $v$ vrtcu. Ljubljana: Zavod Republike Slovenije za šolstvo. . 2018. »Priporočila za uspešen prehod iz vrtca v šolo.« https://www.zrss .si/zrss/wp-content/uploads/priporocila-za-vrtce_prehod_9-julij-2018.pdf. 
- 2019. Strokovna izhodišča posodobitve Koncepta odkrivanja nadarjenih otrok, učencev in dijakov ter vzgojno-izobraževalnega dela z njimi. Ljubljana: Zavod Republike Slovenije za šolstvo.

Željeznov Seničar, M. 2018. Priročnik dobre prakse promocije zdravja v vzgoji in izobraževanju ter socialnem varstvu. Ljubljana: KSJS.

Žnidar, S. 2016. »|zzivi pri načrtovanju dela s predšolskimi nadarjenimi otroki.." V Nadarjeni in talentiran predšolski otrok, ur. M. Željeznov Seničar, 67-73. Ljubljana: MiB.

\section{Transition of a 'Potentially' Gifted Child from Kindergarten to School}

The transition of children from kindergarten to elementary school is poorly studied in research, especially for gifted children. The transition must be based on a vertical connection, an adequate pedagogical and professional continuity of work with the child and an understanding of the child's specificities, which are adequately and optimally considered in the further educational process. In the paper we critically analyse the areas of work with a gifted child in and at school and highlight anomalies in the transition process of a gifted child. We draw attention to several gaps, in particular pedagogical, professional and developmental continuities, the gap between curricula and programme guidelines for working with the gifted, pedagogical approaches and the lack of collaboration between stakeholders in the process prior to basic information about gifted children. We appeal for consideration of the basic rights of gifted children in the educational process, goals, understanding and practices in working with gifted children in preschool and elementary school. Keywords: giftedness, transition, kindergarten, elementary school, parents 